\title{
Effect of Addition of Polyethylene Glycol (PEG) as Plasticizer on Edible Film Characteristics of Milkfish (Chanos Chanos) Skin Gelatin
}

\author{
Nabila Ardianisa*, Eddy Suprayitno** \\ *Department of Fisheries Technology \\ Faculty of Fisheries and marine science \\ Brawijaya university Indonesia \\ ardianisanab@student.ub.ac.id \\ **Department of Fisheries Technology \\ Faculty of Fisheries and marine science \\ Brawijaya university Indonesia \\ eddysuprayitno@ub.ac.id \\ DOI: 10.29322/IJSRP.11.10.2021.p11845 \\ http://dx.doi.org/10.29322/IJSRP.11.10.2021.p11845
}

\begin{abstract}
Gelatin is a type of protein extracted from animal collagen tissue found in animal skin, bones and ligaments or connective tissue. Gelatin has high digestibility properties therefore it has the potential to be the raw material for making edible films. The edible film is a thin layer produced from edible materials. Edible films can be formed from three types of constituent materials, such as hydrocolloids, lipids, and mixtures/composites of the two. Several types of hydrocolloids that are able to make edible films are proteins (gelatin). The test parameters include tensile strength, elongation, thickness, water vapour transmission rate, moisture content and amino acid profile. PEG in edible films is a useful plasticizer to reduce the stiffness of the polymer. The best edible film from milkfish skin gelatin was obtained at a concentration of $1 \%$ polyethylene glycol plasticizer with physicochemical characteristics including tensile strength of $11.94 \mathrm{MPa}$, elongation of $2.55 \%$, thickness of $0.10 \mathrm{~mm}$, water vapour transmission rate of 159.36 $\mathrm{g} / \mathrm{m} 2 / \mathrm{day}$ and water content of $16.03 \%$ with the highest amino acid content, namely Glycine at $172021.41 \mathrm{mg} / \mathrm{kg}$ and the lowest, namely L-Tyrosine at $4333.40 \mathrm{mg} / \mathrm{kg}$.
\end{abstract}

Index Terms- gelatin, edible film, polyethylene glycol, amino acids

\section{INTRODUCTION}

Plenty resource of fisheries in Indonesia made it able to be a potential in protein resources especially animal protein. Fish plays a significant role in fulfilling nutritional sources and securing the necessities of life for humans (Samsudin, 2016). Milkfish is an important economic value fish and has a role in meeting the protein needs of the community (Mas'ud, 2011). Milkfish skin has the potential to be used as gelatin. Gelatin is a type of protein extracted from animal collagen tissue found in animal skin, bones and ligaments or connective tissue (Pantow et al., 2016). Collagen is a protein that provides strength and flexibility to tissues, bones, and skin (Setyowati and Setyani, 2015).

The hydrocolloid type that can be used in edible films production is a protein (gelatin). The edible film cannot be separated from plasticizers as quality enhancing materials (Setyaningrum et al., 2017). Edible films can inhibit food quality degradation such as oxidation, organoleptic changes, microbial growth, and water absorption (Fahrullah et al., 2020). Plasticizers used in the manufacture of edible films should be food grade, edible, and safe for consumption (Marsin and Muhammad, 2016). The addition of polyethylene glycol (PEG) can reduce brittleness because it has a low molecular weight so that it can enter between polymer bonds (Giyatmi et al., 2020).

\section{MATERIALS AND METHODS}

\subsection{Material}

The research materials that were used consisted of raw materials for the manufacture of milkfish skin (Chanos chanos) gelatin, distilled water, citric acid, $\mathrm{pH}$ paper, aluminium foil, label paper, and plastic wrap. Materials for making edible films were milkfish skin gelatin, polyethylene glycol (PEG) plasticizer, distilled water, aluminium foil, and label paper. The materials used in the testing process were gelatin, edible film, distilled water, silica gel, $\mathrm{HCl}$, plastic clips, tissue, and label paper. 
This research method is experimental. In this study, two stages of research were carried out, namely preliminary research and main research. The first stage was the preliminary research which aims to find the optimal concentration of polyethylene glycol (PEG) plasticizer in the process of making the edible film from milkfish skin gelatin. The second stage was the main research conducted after obtaining the optimal concentration of polyethylene glycol (PEG) and reducing the interval on the concentration of polyethylene glycol.

\subsubsection{Making Milkfish (Chanos chanos) Skin Gelatin}

Milkfish skin gelatin was made by preparing the main raw material, which was milkfish skin, cleaned, then soaked in water at $50^{\circ} \mathrm{C}$ for 30 minutes, then washed with running water, then cut into pieces of $1 \mathrm{x} 1 \mathrm{~cm}$ and soaked with citric acid in a ratio of $1: 3$ $(\mathrm{w} / \mathrm{v})$ for 24 hours, then rinsed with running water until the $\mathrm{pH}$ was neutral. The skin was extracted by water bath at a temperature of $60-70^{\circ} \mathrm{C}$ with a ratio of $1: 3(\mathrm{w} / \mathrm{v})$ for 6 hours and then filtered with white cloth, then dried with a dehydrator at a temperature of $60^{\circ} \mathrm{C}$ for \pm 8-12 hours, to obtain gelatin sheets. The last step was grinding the gelatin in a blender.

\subsubsection{Making Edible Film in Preliminary Research}

The first step to make the edible film from milkfish skin gelatin was to weigh milkfish skin gelatin for 5 grams, then dissolved in $100 \mathrm{~mL}$ of distilled water, then heated using a hot plate at a temperature of $60^{\circ} \mathrm{C}$ for \pm 15 minutes, then adding polyethylene glycol (PEG) plasticizer with concentrations of 1\%, 3\% and 5\%. Then reheated the solution using a hot plate at a temperature of $60^{\circ} \mathrm{C}$ for \pm 15 minutes. The edible film solution was poured into an $18 \times 18 \mathrm{~cm}$ tin and dried in an oven at $65^{\circ} \mathrm{C}$ for 18 hours. Furthermore, the peeling process was carried out and obtained edible film sheets from milkfish skin gelatin.

\subsubsection{Making Edible Film in Main Research}

The first step to make the edible film from milkfish skin gelatin was to weigh milkfish skin gelatin for 5 grams, then dissolved in $100 \mathrm{~mL}$ of distilled water, then heated using a hot plate at a temperature of $60^{\circ} \mathrm{C}$ for \pm 15 minutes, then adding polyethylene glycol (PEG) plasticizer with concentrations of $0.5 \%, 1 \%$ and $1.5 \%$. Then reheated the solution using a hot plate at a temperature of $60^{\circ} \mathrm{C}$ for \pm 15 minutes. The edible film solution was poured into an $18 \times 18 \mathrm{~cm}$ tin and dried in an oven at $65^{\circ} \mathrm{C}$ for 18 hours. Furthermore, the peeling process was carried out and obtained edible film sheets from milkfish skin gelatin.

\subsection{Preliminary Research}

\section{RESULT AND DISCUSSION}

\begin{tabular}{ccc}
\hline $\begin{array}{c}\text { Concentration } \\
\text { PEG }\end{array}$ & $\begin{array}{c}\text { Tensile Strength } \\
(\mathrm{MPa})\end{array}$ & Elongation $(\%)$ \\
\hline $1 \%$ & $11.27 \pm 1.19$ & $1.23 \pm 0.10$ \\
$3 \%$ & $7.78 \pm 0.54$ & $1.85 \pm 0.83$ \\
$5 \%$ & $3.89 \pm 1.06$ & $0.61 \pm 0.24$ \\
\hline \multicolumn{3}{r}{ Table 1. Result of Preliminary Research }
\end{tabular}

Preliminary research on edible film from milkfish skin gelatin had different treatments in addition of $1 \%, 3 \%$, and $5 \%$ polyethylene glycol concentration as the plasticizer. The optimum concentration results in preliminary research were obtained by adding $1 \%$ polyethylene glycol concentration. It was indicated by the value of the highest tensile strength parameter, which was 11.27 $\pm 1.19 \mathrm{MPa}$ and the supporting parameter such as elongation with $1.23 \pm 0.10 \%$. The film will be stronger when the tensile test value is higher (Ningrum et al., 2020).

\subsection{Main Research 3.2.1 Tensile Strength}




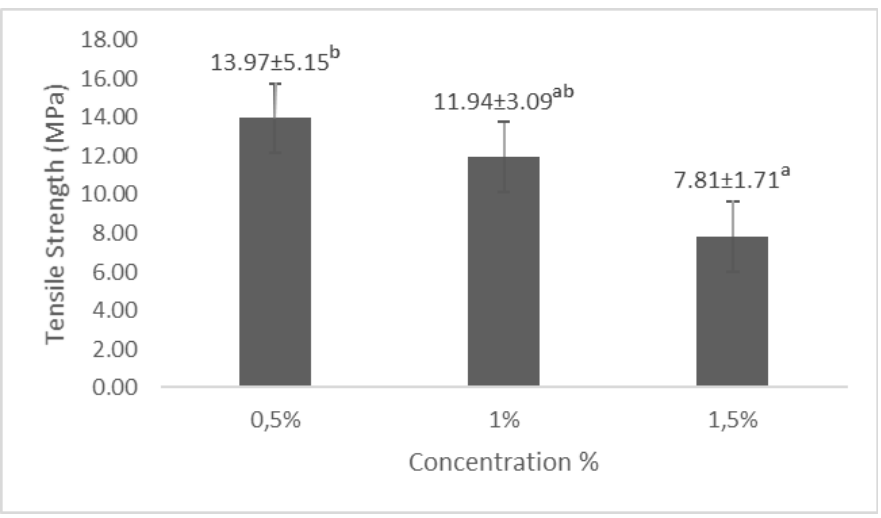

Figure 1. Result of Tensile Strength

Different concentrations of polyethylene glycol (PEG) as plasticizer produces different tensile strength values. At $0.5 \%$ PEG concentration the tensile strength value was $13.97 \mathrm{MPa}, 1 \%$ PEG concentration was $11.94 \mathrm{MPa}$ and $1.5 \%$ PEG concentration was 7.81 $\mathrm{MPa}$. The highest tensile strength value was obtained at the lowest concentration, which was $13.97 \mathrm{MPa}$, and the lowest tensile strength result was obtained at the highest concentration with $7.81 \mathrm{MPa}$. Plenty of plasticizers will decrease the tensile strength and increase the percentage of elongation in edible films because plasticizers able to reduce intermolecular forces and increase the mobility of the biopolymer chain (Khairunnisa et al., 2018).

\subsubsection{Elongation}

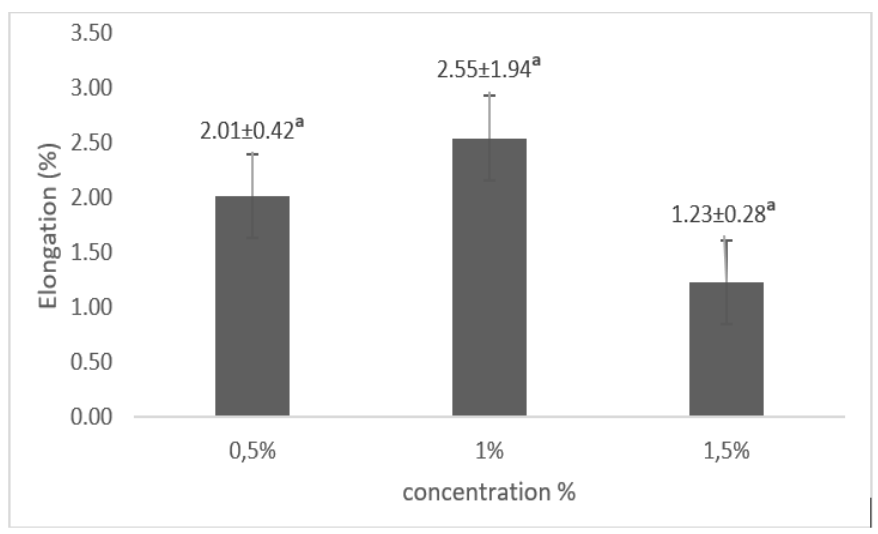

Figure 2. Result of Elongation

The elongation value at $0.5 \%$ polyethylene glycol (PEG) as plasticizer was $2.01 \%, 1 \%$ concentration of $2.55 \%$ and $1.5 \%$ concentration of $1.23 \%$. The highest yield was obtained at $1 \%$ with $2.55 \%$, while the lowest yield was at $1.5 \%$ with $1.23 \%$. PEG as a plasticizer also has a significant effect on the elongation of edible film, as a result of reduced intermolecular forces between polymer chains (Giyatmi et al., 2020).

\subsubsection{Thicknees}




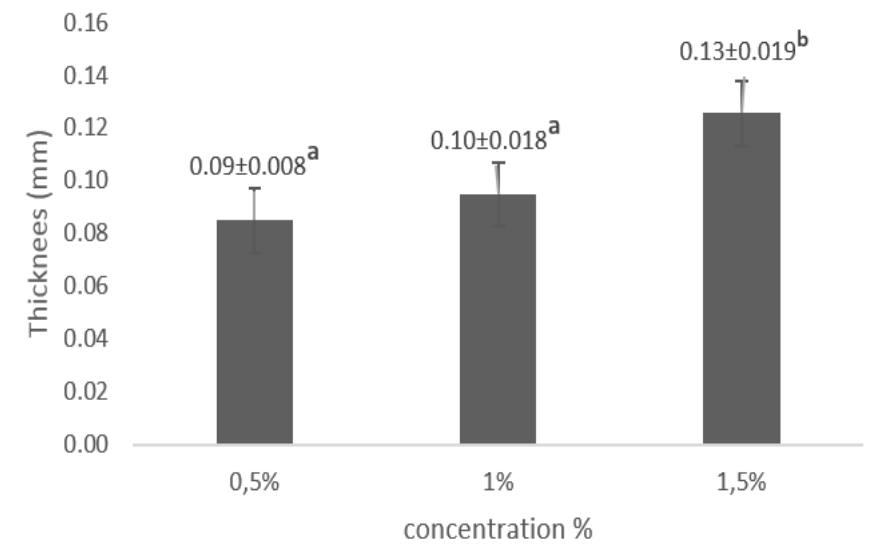

Figure 3. Result of Thicknees

The thickness value at $0.5 \%$ of polyethylene glycol (PEG) as plasticizer was $0.09 \mathrm{~mm}$, and $1 \%$ PEG had $0.10 \mathrm{~mm}$ thickness value lastly $1.5 \%$ PEG had $0.13 \mathrm{~mm}$ thickness value. The highest yield of thickness value was obtained at $1.5 \%$, which was $0.13 \mathrm{~mm}$, while the lowest yield at $0.5 \%$, which was $0.09 \mathrm{~mm}$. With the concentration of polymer and polyethylene glycol (PEG) plasticizer keep increasing, it causes an increase in film thickness. Polyethylene glycol plasticizer has properties that are easily soluble in water and can increase the viscosity of the solution (Gorle et al., 2015). 


\subsubsection{Water Vapor Transmission Rate (WVTR)}

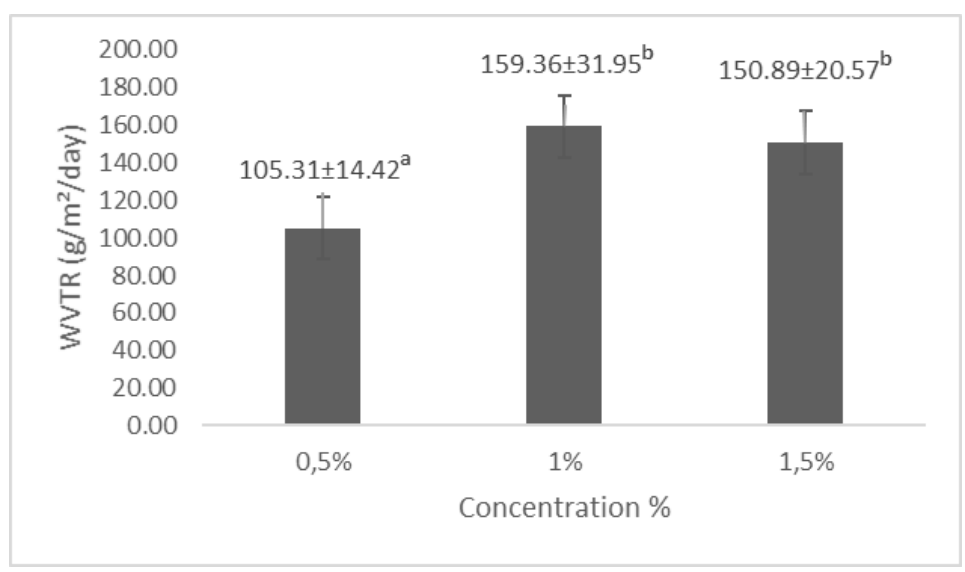

Figure 4. Result of WVTR

Water Vapor Transmission Rate (WVTR) value at $0.5 \%$ polyethylene glycol (PEG) as plasticizer was 105.31 (g/m²/day), $1 \%$ concentration of PEG had $159.36\left(\mathrm{~g} / \mathrm{m}^{2} /\right.$ day $)$ WVTR and PEG concentration at $1.5 \%$ had $150.89\left(\mathrm{~g} / \mathrm{m}^{2} /\right.$ day $)$ WVTR. The highest yield of WVTR obtained at $1 \%$ with $159.36\left(\mathrm{~g} / \mathrm{m}^{2} /\right.$ day $)$, the lowest yield of WVTR was at $0.5 \%$ with $105.31\left(\mathrm{~g} / \mathrm{m}^{2} /\right.$ day $)$. PEG addition in edible films will increase the rate of water vapour transmission due to the widening of the intermolecular space. The increased intermolecular space will provide space for water transmission through the protein matrix in the edible film (Fahrullah et al., 2020).

\subsubsection{Water Content}

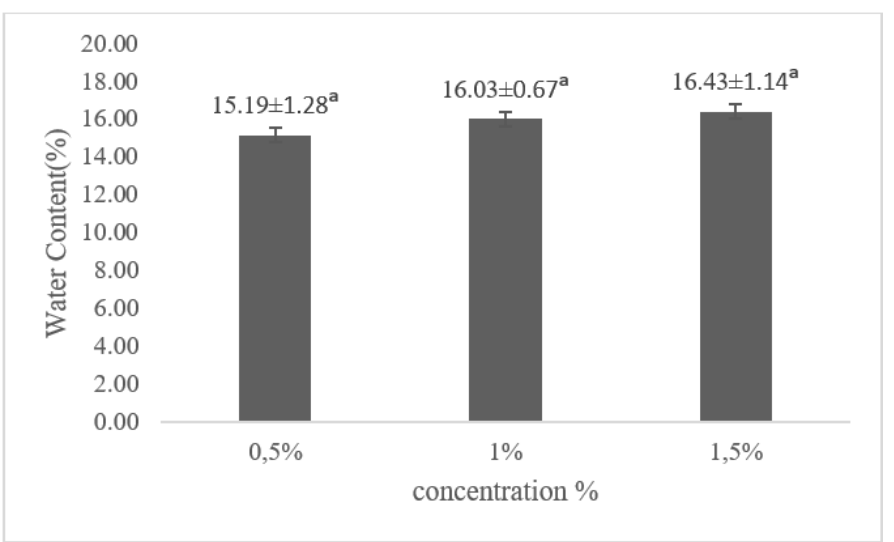

Figure 5. Result of Water Content

The value of water content at $0.5 \%$ polyethylene glycol (PEG) as plasticizer was $15.19 \%, 1 \%$ concentration of PEG had $16.03 \%$ water content and $1.5 \%$ concentration of PEG had $16.43 \%$ water content. The highest yield was obtained at a $1.5 \%$ concentration of PEG with $16.43 \%$ water content, while the lowest yield was at a $0.5 \%$ concentration of PEG with $15.19 \%$ water content. PEG can improve the function of the film as a humectant in edible films. The addition of humectants as a water binder will increase the compactness of the matrix network bonds (hydrogen bonds) therefore it will increase the water content of the product (Sitompul and Zubaidah, 2017). 


\subsection{Amino Acid Profile of Gelatin}

\begin{tabular}{llr}
\hline \multicolumn{1}{c}{ Parameter } & Unit & \multicolumn{1}{c}{ Result } \\
\hline L-Serine & $\mathrm{mg} / \mathrm{kg}$ & 42723.48 \\
L-Glutamic acid & $\mathrm{mg} / \mathrm{kg}$ & 72587.71 \\
L-Phenylalanine & $\mathrm{mg} / \mathrm{kg}$ & 30761.06 \\
L-Isoleucine & $\mathrm{mg} / \mathrm{kg}$ & 13469.80 \\
L-Valine & $\mathrm{mg} / \mathrm{kg}$ & 18640.81 \\
L-Alanine & $\mathrm{mg} / \mathrm{kg}$ & 80440.74 \\
L-Arginine & $\mathrm{mg} / \mathrm{kg}$ & 100337.62 \\
Glycine & $\mathrm{mg} / \mathrm{kg}$ & 269035.32 \\
L-Lysine & $\mathrm{mg} / \mathrm{kg}$ & 25447.80 \\
L-Aspartic Acid & $\mathrm{mg} / \mathrm{kg}$ & 38972.91 \\
L-Leucine & $\mathrm{mg} / \mathrm{kg}$ & 23962.31 \\
L-Tyrosine & $\mathrm{mg} / \mathrm{kg}$ & 7118.81 \\
L-Proline & $\mathrm{mg} / \mathrm{kg}$ & 124585.27 \\
L-Threonine & $\mathrm{mg} / \mathrm{kg}$ & 27995.96 \\
L-Histidine & $\mathrm{mg} / \mathrm{kg}$ & 8143.60 \\
\hline
\end{tabular}

Table 2. Result of Amino Acid Profile from Gelatin

The essential amino acid profile of milkfish skin gelatin was highest in L-Phenylalanine with $30761.06 \mathrm{mg} / \mathrm{kg}$, the lowest was L-Histidine with $8143.60 \mathrm{mg} / \mathrm{kg}$. The highest value of non-essential amino acids in milkfish skin gelatin was glycine with $269035.32 \mathrm{mg} / \mathrm{kg}$ and followed by L-Proline with $124585.27 \mathrm{mg} / \mathrm{kg}$. The lowest yield on L-Tyrosine was $7118.81 \mathrm{mg} / \mathrm{kg}$. Gelatin contains the main constituent amino acids such as glycine, proline and hydroxyproline. Gelatin contains 84-86\% protein and 8-12\% mineral content (Ayunin and Suprayitno, 2019).

\subsection{Amino Acid Profile from Edible Film}

\begin{tabular}{llr}
\hline \multicolumn{1}{c}{ Parameter } & Unit & Result \\
\hline L-Serine & $\mathrm{mg} / \mathrm{kg}$ & 27957.30 \\
L-Glutamic acid & $\mathrm{mg} / \mathrm{kg}$ & 67071.08 \\
L-Phenylalanine & $\mathrm{mg} / \mathrm{kg}$ & 18486.14 \\
L-Isoleucine & $\mathrm{mg} / \mathrm{kg}$ & 10066.39 \\
L-Valine & $\mathrm{mg} / \mathrm{kg}$ & 13500.34 \\
L-Alanine & $\mathrm{mg} / \mathrm{kg}$ & 67280.06 \\
L-Arginine & $\mathrm{mg} / \mathrm{kg}$ & 62359.23 \\
Glycine & $\mathrm{mg} / \mathrm{kg}$ & 172021.41 \\
L-Lysine & $\mathrm{mg} / \mathrm{kg}$ & 24327.01 \\
L-Aspartic Acid & $\mathrm{mg} / \mathrm{kg}$ & 40146.40 \\
L-Leucine & $\mathrm{mg} / \mathrm{kg}$ & 17513.88 \\
L-Tyrosine & $\mathrm{mg} / \mathrm{kg}$ & 4333.40 \\
L-Proline & $\mathrm{mg} / \mathrm{kg}$ & 88470.09 \\
L-Threonine & $\mathrm{mg} / \mathrm{kg}$ & 18171.56 \\
L-Histidine & $\mathrm{mg} / \mathrm{kg}$ & 5037.86 \\
\hline
\end{tabular}

Table 3. Result of Amino Acid Profile from Edible film

The essential amino acid profile of edible film from milkfish skin gelatin was highest in L-lysine, $24327.01 \mathrm{mg} / \mathrm{kg}$, and the lowest was in L-Histidine, which was $5037.86 \mathrm{mg} / \mathrm{kg}$. The highest amino acid profile in non-essential was glycine with 172021.41 $\mathrm{mg} / \mathrm{kg}$, followed by L-Proline with $88470.09 \mathrm{mg} / \mathrm{kg}$. Whilst the lowest yield on L-Tyrosine was $4333.40 \mathrm{mg} / \mathrm{kg}$. Amino acids analysis on edible film from milkfish skin gelatin had the highest value on glycine and was followed by L-Proline. These results were influenced by the raw materials used. These results showed that the value of amino acids in edible films from milkfish skin gelatin decreased compared to amino acids from the gelatin raw materials used. It is because the process of making an edible film there were several stages of heating, resulting in a decrease in the value of amino acids. (Saputra et al., 2015).

The tensile strength parameter in the edible film is the main parameter that has a role in protecting and holding the weight of the packaged product. The high content of the amino acid glycine in gelatin and edible films is closely related to the tensile strength value. According to Adiningsih and Tatik, (2015), the high content of the amino acid glycine in gelatin will play a significant role in the high value of gelatin gel strength. The higher the protein content and the strength value of the gelatin gel used as the main constituent in the manufacture of edible films, the higher the tensile strength value. The high value of gel strength in gelatin indicates 
that gelatin has strong intermolecular forces between polymer chains. The quantity of protein will determine protein-polymer chains in gelatin solution and provide each other with one another (Wijayani et al., 2021).

\section{CONCLUSION}

The optimum concentration of polyethylene glycol (PEG) as plasticizer to produce the edible film from milkfish skin gelatin (Chanos chanos) with the best characteristics, namely $1 \%$ PEG concentration with physicochemical characteristics including tensile strength value of $11.94 \mathrm{MPa}$, elongation of $2.55 \%, 0.10 \mathrm{~mm}$ thickness, water vapour transmission rate of $159.36 \mathrm{~g} / \mathrm{m} 2 / \mathrm{day}$ and water content of $16.03 \%$ with the highest amino acid content, namely Glycine at $172021.41 \mathrm{mg} / \mathrm{kg}$ and the lowest being L-Tyrosine at 4333 , $40 \mathrm{mg} / \mathrm{kg}$.

\section{REFERENCES}

Ayunin, R. Q. dan E. Suprayitno. 2019. Characteristicsof gelatin extracted from red snapper skin (lutjanus argentimaculatus) in difference time extraction. International Journal of Scientific and Research Publications. 9(6). ISSN: 2250-3153.

Fahrullah, F., L. E. Radiati., P. Purwadi dan D. Rosyidi. 2020. The effect of different plasticizers on the characteristics of whey composite edible film. Jurnal Ilmu dan Teknologi Hasil Ternak. 15(1). ISSN: 2338-1620.

Giyatmi., T. A. E. Poetri., H. E. Irianto., D. Fransiska dan Agusman. 2020. Effect of alginate and polyethylene glycol addition on physical and mechanical characteristics of $\kappa$-carrageenan-based edible film. Squalen Bulletin of Marine and Fisheries Postharvest and Biotechnologi. 15(1):41-51. ISSN: 2406-9272.

Khairunnisa, S., Junianto., Zahidah and I. Rostini. 2018. The effect of glycerol concentration as a plasticizer on edible films made from alginate towards its physical characteristic. World Scientific News. 112:130-141. ISSN: 2392-219.

Marsin, A. M. dan I. I. Muhamad. 2016. Preparation and characterization of purple sweet potato starch-based edible film with optimized mixing temperature. Journal of Advanced Reasearch in Material Science. 16(1):1-10. ISSN: 2289-7992.

Mas'ud, F. 2011. Prevalensi dan derajat infeksi dactylogyrus sp. pada insang benih bandeng (Chanos chanos) di tambak tradisional, kecamatan glagah, kabupaten lamongan. Jurnal Ilmiah Perikanan dan Kelautan. 3(1). ISSN: 2528-0759.

Pantow, I. M., M. Sompie., A. D. Mirah., Linda dan M. Karisoh. 2016. Pengaruh perbedaan konsentrasi larutan asam asetat (CH3COOH) terhadap karakteristik gelatin kulit kaki ayam. Jurnal Zootek. 36(1):23-32. ISSN: 0852-2626.

Samsudin, A. M. 2016. Analisis keuntungan komparatif usaha budidaya ikan air tawar di Desa Srikaton Kecamatan Buay Madang Timur Kabupaten Ogan Komering Ulu Timur. JASEP. 2(2):1-6. ISSN: 2443-1001.

Saputra, R.H., I. Widiastuti dan A. Supriadi. 2015. Karakteristik fisik dan kimia gelatin kulit ikan patin (pangasius pangasius) dengan kombinasi berbagai asam dan suhu. Jurnal Teknologi Hasil Perikanan. 1(4):29-36. ISSN: 2302-6936.

Setyaningrum, A., N. K. Sumarni dan J. Hardi. 2017. Sifat fisiko-kimia edible film agar-agar rumput laut (gracilaria sp.) tersubtitusi glycerol. Journal of Science and Technologi. 6(2):136-143. ISSN: 2541-1969.

Setyowati, H. dan W. Setyani. 2015. Potensi nanokolagen limbah sisik ikan sebagai cosmeceutical. Jurnal Farmasi Sains dan Komunitas. 12(1):30-40. ISSN: 1693-5683.

Sitompul, A. J. W. S. Dan E. Zubaidah.2017. pengaruh jenis dan konsentrasi plasticizer terhadap sifat fisik edible film kolang kaling (arenga pinnata). Jurnal Pangan dan Agroindustri. 5(1):13-25. ISSN: 2685-2861.

Wijayani, K. D., Y. S. Darmanto, dan E. Susanto. 2021. Karakteristik edible film dari gelatin kulit ikan yang berbeda. Jurnal Ilmu dan Teknologi Perikanan. 3(1). ISSN:2685-3701. 